\title{
IN VITRO REGULATION OF THE DEO OPERON OF E.COLI AT THE INITIATION OF TRANSCRIPTION
}

\author{
by
}

\author{
BO AHLQUIST SVENNINGSEN ${ }^{1}$
}

University Institute of Biological Chemistry B

83 Sølvgade, DK-1307 Copenhagen, Denmark

1) Present address: Department of Physiology, Carlsberg Laboratory

Gamle Carlsberg Vej 10, DK-2500 Copenhagen, Valby

Keywords: In vitro protein synthesis, transcriptional control, Deo operon, E.coli

The formation of functional mRNA from the Deo operon of Escherichia coli has been investigated in a coupled and uncoupled protein synthesizing in vitro system using the antibiotics rifampicin, streptolydigen and chloramphenicol.

Initiations of transcription take place from 1 to $10 \mathrm{~min}$ after the start of the incubation. Elongation of mRNA proceeds for about $20 \mathrm{~min}$, while translation of mRNA into active enzyme occurs for at least $50 \mathrm{~min}$. In the coupled system the half-life of the deoA mRNA is about $3 \mathrm{~min}$.

Cell-free enzyme synthesis has been carried out by the use of phenol extracted mRNA synthesized either in the presence or absence of amino acids. The amount of enzyme formed is directly proportional to the amount of mRNA added and independent of whether the mRNA has been synthesized in the presence or absence of amino acids.

By separating the transcription of the deoA mRNA from its translation, it has been shown that the DeoR and Cyt $R$ repressors as well as the cyclic AMP-catabolite activator protein control the initiation of transcription. 


\section{INTRODUCTION}

The Deo operon (15) of Escherichia coli contains four cistrons which are combined into two overlapping transcriptional units. One transcript comprises the information of all four Deo genes, and the other that of the last two genes in the series $(2,4,6,7,11,17)$. The enzymes encoded by the operon catalyze the degradation of deoxyribo- and ribonucleosides.

The expression of the tetracistronic unit is subject to double negative control by two repressor proteins encoded in the unlinked $d e o \mathrm{R}$ and $c y t \mathrm{R}$ regulatory genes, respectively. The corresponding inducers are for the DeoR control system deoxyribose-5-phosphate and for the CytR system cytidine and adenosine. Expression of the tetracistronic unit is also dependent on the presence of the cyclic AMPcatabolite activator protein (3). This information has been obtained from both in vivo $(1,12,17)$ and in vitro $(19,20)$ experiments.

The expression of the dicistronic unit is stimulated when wild type cells are grown in the presence of inosine or guanosine through an as yet unidentified regulatory system $(7,11)$.

The present communication deals with the kinetics of formation of functional mRNA of the deoA gene and its product, the thymidine phosphorylase in a cell-free protein synthesizing system. By uncoupling translation from transcription, the regulation of mRNA formation is studied.

\section{NOMENCLATURE}

The symbols of the genes coding for the listed enzymes are: thymidine phosphorylase, deoA (previously designated tpp); deoxyribomutase, deo $\mathrm{B}$ (previously designated drm); purine nucleoside phosphorylase, deoD (previously designated pup); deoxyriboaldolase, deoC (previously designated $d r a$ ); uridine phosphorylase, $u d p$; cytidine deaminase, $c d d$. $d y t \mathrm{R}$ is a regulatory gene for $c d d, u d p, d e o \mathrm{C}, \operatorname{deo} \mathrm{A}, \operatorname{deo} \mathrm{B}$, and $d e o \mathrm{D}$; deo $\mathrm{R}$ is a regulatory gene for $d e o \mathrm{C}$, $\operatorname{deo} \mathrm{A}$, deo $\mathrm{B}$, and $\operatorname{deo} \mathrm{D}$. The Deo operon is defined as the gene cluster consisting of $d e o \mathrm{C}$ $\operatorname{deo} \mathrm{A} d e o \mathrm{~B} d e o \mathrm{D}$. The Deo enzymes are the four enzymes encoded by the Deo operon.

Enzymes: Purine nucleoside phosphorylase or purine nucleoside:orthophosphate (deoxy) ribosyltransferase (EC 2.4.2.1); thymidine phosphorylase or thymidine:orthophosphate deoxyribosyltransferase (EC 2.4.2.4.); uridine phosphorylase or uridine:orthophosphate ribosyltransferase (EC 2.4.2.3); deoxyriboaldolase or 2-deoxy-D-ribose-5-phosphate: acetaldehydelyase (EC 4.1.2.4), phosphodeoxyribomutase (EC 2.7.5.6).

\section{MATERIALS}

The wild type Deo operon DNA was isolated according to $(15,23)$ from bacteriophages produced from the double lysogenic strain $S \emptyset$ $539 \mathrm{~F}^{-} \Delta$ deo thi leu ( $\lambda \mathrm{CI} 857 \mathrm{~S} 7$ ) ( $\lambda \mathrm{CI} 857 \mathrm{~S} 7$ $\mathrm{d}$ deo) (14). The $\mathrm{S}-30$ supernatant containing the enzymes, ribosomes and cofactors necessary for transcription and translation was prepared from the strain S $\varnothing 928$ (BS 253) HfrH $\Delta$ deo-11, $\Delta$ lac, thi, udp, upp, ton $(19,20)$ if the repressors for the Deo operon were required and from the strain S $\emptyset 931 \mathrm{HfrH} c y t \mathrm{R} 15, \operatorname{deo} \mathrm{R} 7, \operatorname{clm} \mathrm{A}, \Delta$ deo-11, $\triangle$ lac, thi, udp, upp, ton (20) if the presence of active repressors was undesirable.

Substrates and other reagents were obtained from the companies indicated in parenthesis: ATP, GTP, CTP, UTP and E.coli tRNA (Boehringer, Mannheim); trisodium phosphoenol pyruvate (Calbiochem.); dithiothreitol, cyclic AMP, thymidine (Sigma Chemical Company); folinic acid („Leucovorin«, Lederle); polyethylene glycol 6000 (Sigma Chemical Company); chloramphenicol (Sigma Chemical Company); rifampicin (Sigma Chemical Company); streptolydigen (a gift from John Whitfield, Upjohn Company). Coformycin was generously provided by Dr. $H$. Umezawa, Institute of Microbial Chemistry, Tokyo. Tetrahydrouridine was a gift from P. Valentin, Institute of Biological Chemistry B, Copenhagen.

\section{METHODS}

4.1. DNA directed enzyme synthesis was carried out as described in $(19,20)$. The incubations contained per ml: $44 \mu$ moles Tris-acetate $(\mathrm{pH}$ 8.2); $1.37 \mu$ moles dithiothreitol; $55 \mu$ moles potassium acetate; 27 $\mu$ moles ammonium acetate; $14 \mu$ moles magnesium acetate; 7.4 
$\mu$ moles calcium acetate; $0.22 \mu$ moles each of 20 amino acids; $2.2 \mu$ moles ATP; $0.55 \mu$ moles each of GTP, CTP and UTP; $21 \mu$ moles trisodium phosphoenolpyruvic acid; $100 \mu \mathrm{g}$ of E.coli tRNA; $27 \mu \mathrm{g}$ folinic acid; $20 \mathrm{mg}$ polyethylene glycol $6000 ; 6.5 \mathrm{mg} \mathrm{S}-30$ protein and 0-50 $\mu \mathrm{g}$ deo DNA.

\subsection{RNA directed enzyme synthesis in the uncoupled system}

Transcription proceeded in the absence of amino acids in an incubation mixture containing per ml: $44 \mu$ moles Tris-acetate (pH 8.2); 1.37 $\mu$ moles dithiothreitol; 55 umoles potassium acetate; 27 moles ammonium acetate; 11.7 $\mu$ moles magnesium acetate; $7.4 \mu$ moles calcium acetate; $2.2 \mu$ moles ATP; $0.55 \mu$ moles each of GTP, CTP and UTP; $21 \mu$ moles trisodium phosphoenolpyruvic acid; $100 \mu \mathrm{g}$ of E.coli tRNA; $27 \mu \mathrm{g}$ folinic acid; $20 \mathrm{mg}$ polyethylene glycol $6000 ; 6.5 \mathrm{mg}$ of S-30 protein and $10-40 \mu \mathrm{g}$ deo DNA. The reaction mixture (total volume $0.2 \mathrm{ml}$ ) was incubated $8 \mathrm{~min}$ at $37^{\circ} \mathrm{C}$. Initiations of transcription were terminated by the addition of rifampicin $(10 \mu \mathrm{g} / \mathrm{ml}$ final concentration) and elongation of mRNA by addition of streptolydigen $(100 \mu \mathrm{g} / \mathrm{ml})$. At the same time translation was started by the addition of 0.22 $\mu$ mole each of the 20 amino acids. After an additional 40 min incubation, synthesis was terminated by a 1 to 5 dilution of the reaction mixture with ice-cold Trisbuffer (10 mM-Tris-HCl $(\mathrm{pH} \quad 7.6), \quad 50 \quad \mu \mathrm{M}-$ EDTA, $\quad 50 \quad \mu \mathrm{g} / \mathrm{ml}$ chloramphenicol).

\subsection{In vitro enzyme synthesis directed by phenol extracted RNA}

mRNA for cell-free enzyme synthesis was extracted according to (18) from $4 \mathrm{ml}$ of a DNA directed synthesis mixture which had been incubated for $18 \mathrm{~min}$ at $37^{\circ} \mathrm{C}$ with $40 \mu \mathrm{g} / \mathrm{ml}$ of deo DNA in the presence or absence of amino acids. To terminate RNA synthesis, DNase was added to a final concentration of $20 \mu \mathrm{g} / \mathrm{ml}$. After $2 \mathrm{~min}$ at $37^{\circ} \mathrm{C}$, the solution was made $20 \mathrm{mM}$ for EDTA and mixed with an equal volume of ice-cold phenol which had been saturated with water. The mixture was shaken for $10 \mathrm{~min}$ at $4^{\circ} \mathrm{C}$ and centrifuged to separate the two phases. To the water phase was added $200 \mu \mathrm{l}$ of $1.0 \mathrm{M}$ sodium acetate $(\mathrm{pH}$ 5.2) and the RNA precipitated with $96 \%$ ethanol using 2.5 times the volume of the solution. After at least one hour at $-20^{\circ} \mathrm{C}$, the precipitate was collected by centrifugation at $4,000 \mathrm{~g}$ for $10 \mathrm{~min}$ and dissolved in $600 \mu \mathrm{l}$ of $20 \mathrm{mM}$-Tris-acetate buffer (pH 8.2) containing $2 \%$ polyethylene glycol. After overnight dialysis against three changes of $20 \mathrm{~mm}$-Tris-acetate, the RNA containing solution was stored at $-20^{\circ} \mathrm{C}$ until used.

Conditions for RNA directed enzyme synthesis were as for DNA directed synthesis with the following modifications: mRNA in concentrations of $0-3 \mathrm{mg} / \mathrm{ml}$ was substituted for DNA and streptolydigen was added to a final concentration of $100 \mu \mathrm{g} / \mathrm{ml}$.

\subsection{Assay for thymidine phosphorylase}

Assay mixtures contained $5.7 \mathrm{~mm}$-thymidine, $10.0 \mathrm{mM}$-phosphate $\mathrm{pH} 7.3,10 \mathrm{~mm}$-Tris- $\mathrm{HCl}$ pH 7.3, 2 mm-EDTA and extract in a final volume of $0.35 \mathrm{ml}$. Three to ten enzyme units per $\mathrm{ml}$ of assay mixture were used as standard, one unit of enzyme activity being defined as the amount of enzyme which degrades 1 nmole of substrate per min.

At $0^{\prime}, 10^{\prime}$ and $20^{\prime} 100 \mu \mathrm{l}$ samples were taken into $200 \mu \mathrm{l} \mathrm{M-perchloric} \mathrm{acid.} \mathrm{The} \mathrm{amount} \mathrm{of}$ thiobarbituric acid reacting material from deoxyribose-1-phosphate formed in the reaction was determined as described in (11). Enzyme activities are given for the 5 times diluted incubation mixtures.

\section{RESULTS AND DISCUSSION}

\subsection{Kinetics of the formation of functional deoA mRNA and thymidine phosphorylase in the DNA-directed coupled in vitro system}

Three inhibitors can be used to follow the formation of $\operatorname{deo\mathrm {A}} \mathrm{mRNA}$ and its translational product, the thymidine phosphorylase in a DNA-directed coupled in vitro system: 1) Chloramphenicol blocks the translation of mRNA. 2) Rifampicin blocks the initiation of transcription (21) but does not interfere with the elongation of mRNA molecules already in- 
itiated or the translation process. 3) Streptolydigen prevents the elongation of nascent mRNA molecules (10) but has no effect on the translation process. Each of the three inhibitors was added at various times after the start of the incubation and the incubations were continued for $40 \mathrm{~min}$. Thereafter the activity of thymidine phosphorylase was measured. This enzyme is the product of the second gene of the Deo operon and a measure of the translation of the tetracistronic mRNA unit of the Deo operon (19). In order to avoid the presence of active repressors, the $\mathrm{S}-30$ extract prepared from the constitutive mutant cyt $\mathrm{R} 15$, deo $\mathrm{R} 7$ was used in these experiments.

The curve obtained by adding chloramphenicol at various times after the start of the incubation (Fig. 1) reveals the amount of enzyme

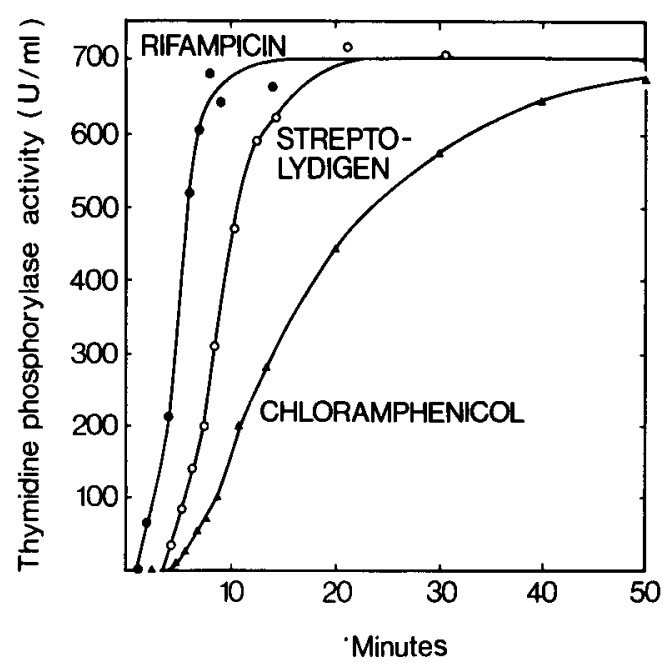

Figure 1. Kinetics of formation of functional deo mRNA and enzyme in the coupled transcriptiontranslation system. Cell-free synthesis of thymidine phosphorylase was carried out with an S-30 extract from the constitutive mutant cyt $\mathrm{R} 15$ deo $\mathrm{R} 7$. The synthesis mixture contained $33 \mu \mathrm{g} / \mathrm{ml}$ deo DNA and 250 $\mu \mathrm{M}$-cAMP. At different times after the start of the incubation, rifampicin $(10 \mu \mathrm{g} / \mathrm{ml})$ or streptolydigen $(100$ $\mu \mathrm{g} / \mathrm{ml})$ or chloramphenicol $(100 \mu \mathrm{g} / \mathrm{ml})$ were added and the incubation continued for $40 \mathrm{~min}$.

which had been formed at the time of the addition of the antibioticum. The curve has a sigmoidal shape and shows that enzyme is syn- thesized after a lag period of 5 min during 35 min of incubation.

Streptolydigen inhibits transcription and the amount of enzyme formed after the addition of this antibioticum is a measure of the number of completed mRNA molecules present at the moment of addition. The curve for streptolydigen in Figure 1 reveals that no mRNA is completed until after $4 \mathrm{~min}$ from the start of the incubation. After 20 min all mRNA which can support enzyme synthesis is completed. At any one time the difference between the thymidine phosphorylase activity measured after addition of streptolydigen and that after addition of chloramphenicol is expected to be proportional to the amount of functional mRNA present in the coupled system. In agreement with the expectation, the difference increases between 6 and $10 \mathrm{~min}$ after the start of the incubation. Thereafter the difference, i.e. the apparent amount of functional mRNA remains constant up to $15 \mathrm{~min}$ and then diminishes. This indicates either break-down of functional mRNA or a gradual exhaustion of the system to support transcription and translation.

The amount of thymidine phosphorylase activity obtained after addition of rifampicin determines the number of initiations of transcription which had occurred at the time of the addition. As seen in Figure 1, the number of initiations increases rapidly after the first 1.2 min of incubation and stops after $10 \mathrm{~min}$. This implies that the system can support transcription only during the first $10 \mathrm{~min}$ of incubation. Thereafter the substrates or cofactors necessary for the RNA polymerase may become limiting or compounds like nucleoside diphosphates reach inhibitory concentrations.

Some deductions as to the rate of transcription and the half-life of the mRNA can be made for the early period of this protein synthesizing system. The distance in time between the rifampicin and the streptolydigen curves should correspond to the time required to form a functional message. During the first minutes of incubation, the curves are separated by a time difference of $3 \mathrm{~min}$. As the first and second gene of the Deo operon (deoC and $\operatorname{deo} \mathrm{A}$ ) together consist of approximately 1,900 base pairs (14) the apparent rate of transcription am- 
ounts to 10 bases per second. At 6 min after the start of incubation, the apparent rate has dropped to 6 bases per second.

Since the chloramphenicol and streptolydigen curves intercept with the abscissa at the same point transcription and translation are tightly coupled. The fact that the two curves diverge even at short incubation times indicates a considerable turn-over of the deoA mRNA. Assuming equal rates of transcription and translation, the distance between the curves at the time of the highest activity should represent the mean-life of functional deoA mRNA. The distance is about $4 \mathrm{~min}$ which means that the half-life of the mRNA is In $2 \times 4 \mathrm{~min}=2.8 \mathrm{~min}(8)$. This value is low when compared with the $6-7 \mathrm{~min}$ found for the gal genes (18), the 10 min reported for the lacz gene (13), or the 30 min determined for the trp genes (22) in similar in vitro systems. A half-life of about $3 \mathrm{~min}$ is, however, comparable to the half-life of 0.5 to $2 \mathrm{~min}$ found for these genes in vivo $(5,9)$.

\subsection{Kinetics of the formation of functional $\operatorname{deo} A$ mRNA and thymidine phosphorylase in an uncoupled system}

As described under 4.2 the formation of mRNA can be separated from its translation by starting the incubation without amino acids. After a certain time, transcription is blocked by the addition of rifampicin or streptolydigen and the formed messenger is translated by providing amino acids as substrates. This switch has been performed at various times after the beginning of the incubation and the amount of thymidine phosphorylase obtained is plotted in Figure 2. The procedure gave a much lower enzyme yield than the coupled system. The number of initiations of mRNA as indicated by the rifampicin curve increases between 2 and $12 \mathrm{~min}$ after the start of incubation, whereafter no additional initiations were observed. The streptolydigen curve, indicative of the capacity of translation from completed mRNA molecules, levels off after about 15 min with low enzyme values. Whereas ribosome binding to elongating mRNA molecules and translation is relatively efficient (rifampicin curve) this

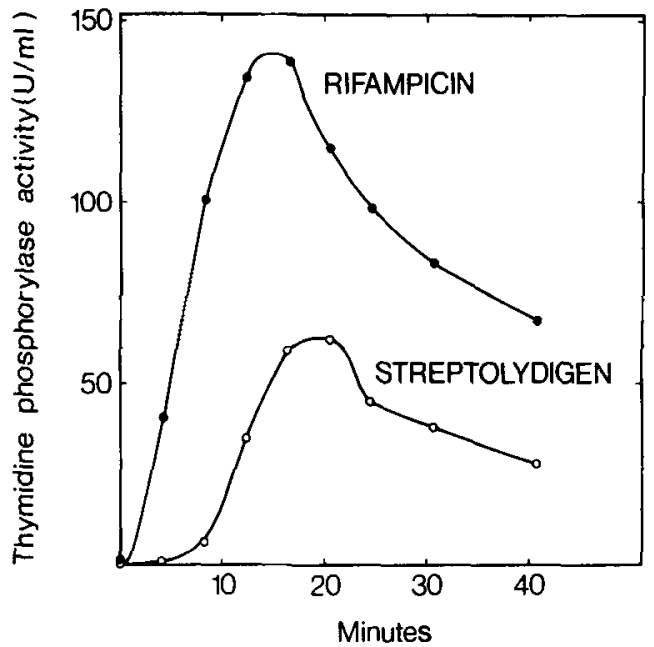

Figure 2. Kinetics of formation of functional deo mRNA and enzyme in the uncoupled system. RNA synthesis was carried out in the absence of amino acids with an $\$-30$ extract from the constitutive mutant cyt $\mathrm{R} 15 \operatorname{deo} \mathrm{R} 7$ in the presence of $21 \mu \mathrm{g} / \mathrm{ml}$ deo DNA and $250 \mu \mathrm{M}$-cAMP. At various times after the onset of incubation, amino acids were added to give a final concentration of $220 \mu \mathrm{M}$ per amino acid. At the same time rifampicin $(10 \mu \mathrm{g} / \mathrm{ml})$ or streptolydigen $(100 \mu \mathrm{g} / \mathrm{ml})$ were added and the incubation continued for $40 \mathrm{~min}$.

does not seem to hold for completed messages, perhaps due to their susceptibility for degradation by nucleases or to a conformational state inhibitory towards translation.

\subsection{The amount of thymidine phosphorylase obtained in a translation system from phenol-extracted mRNA}

The deo mRNA was transcribed in the presence or absence of amino acids as detailed under 4.3 and extracted with phenol. Isolated mRNA was added in increasing amounts to the cell-free protein synthesizing system and thymidine phosphorylase measured after 40 min incubation (Fig. 3). Streptolydigen had been added to safe-guard against any endogenous transcription. Up to a concentration of $1.5 \mathrm{mg} \mathrm{RNA} / \mathrm{ml}$ the amount of thymidine phosphorylase synthesized was a linear function of the added mRNA. No difference is observable between mRNA made in the presence or absence of amino acids. The 


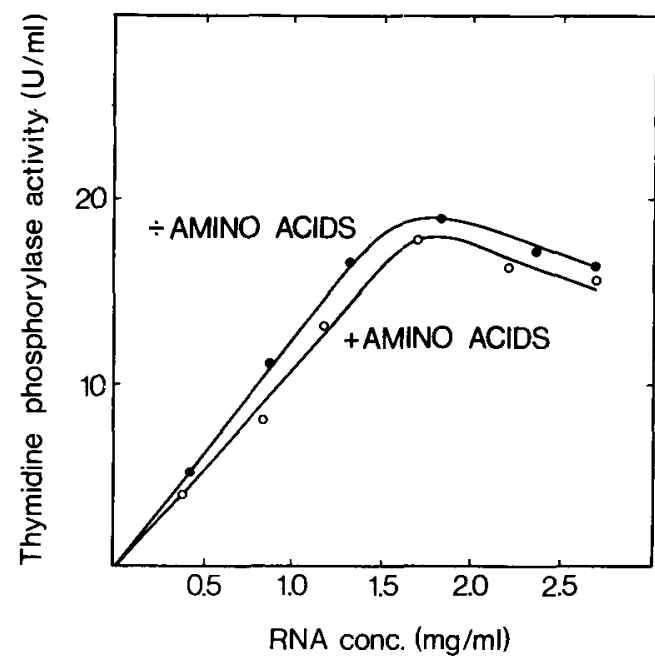

Figure 3. RNA-directed synthesis of thymidine phosphorylase from mRNA transcribed in the presence or absence of amino acids.

Table I

In vitro induction of thymidine phosphorylase mRNA results indicate that the synthesis of thymidine phosphorylase is not regulated by a negative control mechanism at the level of translation of mRNA.

\subsection{The CytR, DeoR and cyclic AMP-catabolite activator protein control mechanisms}

In order to study the effect of the products of the wild type alleles of the $d e o \mathrm{R}$ and $c y t \mathrm{R}$ regulatory genes in the DNA-directed coupled in vitro system the experiments listed in Table I were performed using an S-30 supernatant from bacteria containing these alleles. Transcription was started in the absence of amino acids. After $8 \mathrm{~min}$ the initiation of transcription was blocked with rifampicin and amino acids were added to permit translation.

It is apparent from the Table that the inducer deoxyribose-5-phosphate has to be present at

\begin{tabular}{|c|c|c|c|}
\hline Time: & $0 \mathrm{~min}$ & $8 \mathrm{~min}$ & $38 \mathrm{~min}$ \\
\hline Experiment & added & $\begin{array}{l}\text { added } \\
\text { rifampicin }(10 \mu \mathrm{g} / \mathrm{ml}) \\
\text { amino acids }(220 \mu \mathrm{M})\end{array}$ & $\begin{array}{l}\text { thymidine } \\
\text { phosphorylase } \\
\text { units } / \text { ml }\end{array}$ \\
\hline 1 & - & - & 1.5 \\
\hline 2 & $\begin{array}{l}\text { deoxyribose-5 } \\
\text {-phosphate }\end{array}$ & - & 24.5 \\
\hline 3 & - & $\begin{array}{l}\text { deoxyribose-5 } \\
\text {-phosphate }\end{array}$ & 0.9 \\
\hline 4 & cyclic AMP & - & 5.8 \\
\hline 5 & - & cyclic AMP & 0.8 \\
\hline 6 & $\begin{array}{l}\text { cytidine } \\
+ \text { cyclic AMP }\end{array}$ & - & 25.6 \\
\hline 7 & cyclic AMP & cytidine & 7.6 \\
\hline 8 & $\begin{array}{l}\text { adenosine } \\
\text { + cyclic AMP }\end{array}$ & - & 24.6 \\
\hline 9 & cyclic AMP & adenosine & 8.6 \\
\hline
\end{tabular}

Transcription of the deoA gene is carried out in the presence of an S-30 extract from bacteria containing wild type alleles of the $c y t \mathrm{R}$ and $d e o \mathrm{R}$ regulatory genes. $8 \mathrm{~min}$ after the start of the incubation, initiation of transeription is blocked by addition of rifampicin and translation initiated by addition of amino acids. In order to prevent deamination of the co-inducers cytidine and adenosine, tetrahydrouridine $(250 \mu \mathrm{M})$ and coformycin $(5 \mu \mathrm{M})$, respectively, are added in experiments 6-9. The concentrations of effector were: $250 \mu \mathrm{M}$-deoxyribose-5-phosphate, $250 \mu \mathrm{M}$-cyclic AMP, $50 \mu \mathrm{M}$-cytidine, $500 \mu \mathrm{M}$-adenosine. 
the time of initiation of transcription to permit the synthesis of significant amounts of thymidine phosphorylase. Likewise, the co-inducers of the cyt $\mathrm{R}$ repressor - cytidine or adenosine - are effective together with cyclic AMP only during the first $8 \mathrm{~min}$ of the experiment, i.e. when initiation of transcripts can occur. Addition of the effectors, after initiation of transcription is blocked, but before elongation is completed, does not stimulate enzyme synthesis. It can be concluded that the two repressors and the cyclic AMP-catabolite activator proteins act in vitro on the operatorregions of Deo operon.

\section{ACKNOWLEDGEMENT}

I would like to thank professor AGNETE MUNCH-PETERSEN for many valuable and stimulating discussions during my stay at the Institute of Biological Chemistry B.

\section{REFERENCES}

1. Ahmad, S. I. \& R. H. Pritchard: A regulatory mutant affecting the synthesis of enzymes involved in the catabolism of nucleosides in Escherichia coli. Molec. gen Genet. 111, 77-83 (1971)

2. Albrechtsen, H., K. Hammer-Jespersen, A. MunCh-Petersen \& N. Fill: Multiple regulation of nucleoside catabolizing enzymes: Effects of a polar dra mutation of the deo enzymes. Molec. gen. Genet. 146, 139-145 (1976)

3. ANderson, W. B., A. B. SChNeider, M. EMmer, R. L. Perlman \& I. Pastan: Purification of and properties of the cyclic adenosine 3', 5'-monophosphate receptor protein which mediates cyclic adenosine 3',5'-monophosphate-dependent gene transcription in Escherichia coli. J. Biol. Chem. 246, 5929-5937 (1971)

4. Baumanis, G. E., Y. V. Smirnov \& V. V. SUKHODOLETZ: Production and study of polar mutants for nucleoside catabolism liked genes in Escherichia coli. Genetika 10(5), 81-88 (1974)

5. Blundell, M., E. Craig \& D. Kennell: Decay rates of different mRNA in E.coli and models of decay. Nature New Biol. 238, 46-49 (1972)

6. Buxton, R. S.: Genetic analysis of thymidineresistant and low-thymidine requiring mutants of Escherichia coli $\mathrm{K} 12$ induced by bacteriophage Mu-1. J. Bact. 121, 475-484 (1975)
7. Buxton, R. S., H. Albrechtsen \& K. HammerJESPERSEN: Overlapping transcriptional units in the deo operon of Escherichia coli $K$ 12: Evidence from phage $\mathrm{Mu}-1$ insertion mutants. J. Mol. Biol. 114, 287-300 (1977)

8. Dalbow, D. G. \& R. Young: Synthesis time of $\beta$ galactosidase in Escherichia coli $B / r$ as a function of growth rate. Biochem. J. 150, 13-20 (1975)

9. ForchHammer, J., E. N. JaCKSON \& C. YANOFSKY: Different half-lives of messenger RNA corresponding to different segments of the tryptophan operon of Escherichia coli. J. Mol. Biol. 71, 687-699 (1972)

10. Goldberg, I. H. \& P. A. Friedman: Antibiotics and nucleic acids. Ann. Rev. Biochem. 40, 775810 (1971)

11. Hammer-Jespersen, K., A. Munch-Petersen, P. NygaARd \& M. SCHWARTZ: Induction of enzymes involved in the catabolism of deoxyribonucleosides and ribonucleosides in Escherichia coli K 12. Europ. J. Biochem. 19, 533538 (1971)

12. Hammer-Jespersen, K. \& A. Munch-Petersen: Multiple regulation of nucleoside catabolizing enzymes: Regulation of the deo operon by the $c y t \mathrm{R}$ and $d e o \mathrm{R}$ gene products. Molec. gen. Genet. 137, 327-335(1975)

13. JONSEN, M.: Personal communications

14. Jørgensen, P., J. Collins \& P. ValentinHANSEN: On the structure of the deo operon of Escherichia coli. Molec. gen. Genet. 155, 93-102 (1977)

15. Lomax, M. S. \& G. R. Greenberg: Characteristics of the deo operon: Role in thymine utilization and sensitivity to deoxyribonucleosides. J. Bact. 96, 501-514 (1968)

16. Miller, J. H.: Experiments in molecular genetics. Cold Spring Harbor Laboratory, pp. 422-423 (1972)

17. Munch-Petersen, A., P. NygaArd, K. HammerJeSPERSEN \& N. FIIL: Mutants constitutive for nucleoside catabolizing enzymes in Escherichia coli K 12. Europ. J. Biochem. 27, 208-215 (1972)

18. SChumacher, G. \& R. Ehring: RNA-directed cell-free synthesis of the galactose enzymes of Escherichia coli. Molec. gen. Genet. 124, 329-344 (1973)

19. Svenningsen, B. A.: Regulated in vitro synthesis of the enzymes of the deo operon of Escherichia coli. Properties of the DNA-directed system. Molec. gen. Genet. 137, 289-304 (1975)

20. Valentin-Hansen, P., B. A. Svenningsen, A. MunCh-PETERSEN \& K. Hammer-Jespersen: In vitro regulation of the Deo operon: the double negative control of the Deo operon by the cytR 
and DeoR repressors in a DNA directed in vitro system. Molec. gen. Genet. (in press)

21. Wehrli, W. \& M. Staehelin: Actions of the rifamycins. Bact. Rev. 35, 290-309 (1971)

22. Zalkin, H., C. Yanofsky \& C. L. SQuires: Regulated in vitro synthesis of Escherichia coli tryptophan operon messenger ribonucleic acid and enzymes. J. Biol. Chem. 249 (2), 465-475 (1974)
23. Zubay, G.: In vitro synthesis of protein in microbial systems. Ann. Rev. Genet. 7, 267-287 (1973) 